\title{
Radyofrekansın kas iskelet sistemi hastalıklarında kullanımı
}

\author{
Use of radiofrequency for musculoskeletal system diseases
}

\author{
Hayati Aygün, Osman Yaray
}

Özel Medicabil Hastanesi Ortopedi ve Travmatoloji Kliniği, Bursa

\begin{abstract}
Radyofrekans (RF) enerjisi, kas iskelet sisteminde ise insizyon yapma, hemostazis, kaspüler gevşetme ya da kapsülorafi gibi birçok cerrahi girişimde yer alırken, radyofrekans ablasyon da yine bazı tümörlerin ve kronik ağrıların tedavisinde kullanılmaktadır. 1950'li yıllardan günümüze kadar devam eden süreç içerisinde, daha gelişmiş sistemler üretilmiş ve radyofrekansın canlı dokuya istenen miktar ve süre içerisinde güvenle aktarılabilmesi sağlanmıştır. Radyofrekans, özellikle gelişmiş elektrodlar sayesinde perkütan nörotomi ya da bazı tümörlerin ablasyonu için uygulanabilirken, açık ya da artroskopik/endoskopik cerrahi yaklaşımların bir komponenti olmuştur. Enfeksiyon ve kanama diyatezi gibi bazı durumlar RF ablasyon uygulamalarına kontrendikasyon oluştururken, küçük oranlarda da olsa komplikasyonlar görülebilmektedir. Elektrodların doğru bölgeye mümkün olan en ideal biçimde yerleştirilmesi ve bu amaçla ultrasonografi, bilgisayarlı tomografi ve floroskopi gibi radyolojik kılavuz yöntemlerin kullanılması, işlemin başarısı ve komplikasyonlarından kaçınılması için zorunludur. Hastalara günübirlik ayaktan tedavi şeklinde, mini-invaziv ya da perkütan uygulanabilmesi yanında tekrarlanabiliyor olması önemli avantajlarındandır. Ancak, pahalı olması ve yardımcı kılavuz görüntüleme sistemlerine gereksinim duyulması en önemli dezavantajlarıdır.
\end{abstract}

Anahtar sözcükler: radyofrekans ablasyon; RFA; perkütan nörotomi; kronik ağrı
Radiofrequency energy is used in many surgical procedures such as incision making, hemostasis, capsular release and capsulorraphy in the musculoskeletal system, while radiofrequency ablation is also used in the treatment of some tumors and chronic pain, in almost every field of the medicine. Since 1950, more advanced systems were produced, and it was ensured that the radiofrequency can be transmitted safely to live tissue within the desired amount and time. While it can be used for percutaneous neurotomy or the ablation of some tumors in open surgical areas especially with the help of advanced electrodes, it has been a component of arthroscopic/endoscopic surgical approaches. Some situations, such as infection and bleeding diathesis, are contraindications to RF ablation practices; minor complications may also be seen. The placement of the electrodes in the correct region as best as possible, and the use of radiological guiding methods such as ultrasound, computed tomography and fluoroscopy for this purpose is essential for the success of the procedure and avoidance of complications. The most important advantage of the radiofrequency is that it can be performed percutaneously, being repeatable and safe on daily outpatient when applied with the purpose of ablation. However, most important disadvantages are that it is expensive, and requires assistive guidance of imaging systems.

Key words: radiofrequency ablation; RFA; percutaneous neurotomy; chronic pain

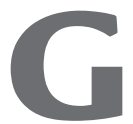

eçtiğimiz son 10-15 yılda, perkütan tedavi ve girişim yöntemleri oldukça rağbet görmeye başlamıştır. Minimal invaziv tedavi yöntemleri adı altında yaygınlaşan bu tür uygulamalar, gerek ağrı tedavisi ve gerekse cerrahi uygulamalarda geçen her gün alanını genişletmektedir. Özellikle tümör cerrahisi ve ağrı tedavisinde, radyolojik kılavuz yöntemler yardımı ile uygulandığında önemli avantajlar sağlamaktadır. Diğer taraftan, estetik işlemlerde temel ve yardımcı araç olarak yararlanılmakta olup, bu konu makalenin kapsamı dışında tutulacaktır.
Canlı dokuya uygulanabilen radyofrekans sistemi ilk defa 1950'lerde üretilmiştir. 1970'li yılların ortalarında, servikal ve lomber vertebrada faset eklem patolojilerine karşı uygulanmıştır; ancak, 22 gauge radyofrekans kanülü 1981'de üretilebilmiş ve bu tarihten sonra çok az sayıda olguda, sınırları kontrol edilebilir radyofrekans ablasyon uygulamaları mümkün olmuştur. Ama, gerek yara yeri sorunları ve gerekse motor defisite varan ciddi kontrol edilemeyen komplikasyonlar nedeni ile yaygınlaşamamıştır. Radyofrekans dalgalarının istenen bölgeye istenen süre ve miktarda

- Illetişim adresi: Doç. Dr. Hayati Aygün, Özel Medicabil Hastanesi Ortopedi / Omurga Cerrahisi Kliniği, Nilüfer, Bursa Tel: 0224 - 2415533 e-posta: hayatiaygun@gmail.com

- Geliș tarihi: 20 Mart 2017 Kabul tarihi: 20 Mart 2017 
transferine imkan tanıyan cihazların üretilmesi 1990’ı yıllarda olmuş, bundan sonra bu cihazlar oldukça yaygın kullanım alanı bulmuştur. ${ }^{[1-3]}$

Radyofrekans kullanımı, esas itibarı ile dokuların ablasyonu yani eritilmesi (koagülatif nekroz) ya da tahrip edilmesi temeline dayanmaktadır. Dolayısıyla, literatürde radyofrekans uygulamaları 'Radyofrekans Ablasyon Tedavisi' olarak isimlendirilmiş ve RFAT şeklinde kısaltılmıştır. Biz de bundan sonraki isimlendirmelerde RF (radyofrekans), RFA (radyofrekans ablasyon) ve RFAT (radyofrekans ablasyon tedavisi) kısaltmalarını kullanacağız. RFA uygulamaları; çeşitli ağrıların giderilmesi için ve bazı tümörlerin tedavisi amacı ile perkütan, bazen endoskopik uygulamalarda minimal invaziv (MIS) ve bazen de yine özellikle tümör cerrahisinde açık cerrahinin bir komponenti olarak uygulanabilen bir teknolojik enstrümandır. RFA'da, hastalık ya da ağrı nedeni olan dokulara RF dalgalarının bu üç yöntemden biri ya da daha fazlası kullanılarak ulaştırılması ve bu dalgaların arzu edildiği şekilde ilgili dokuları etkilemesi temeline dayanan bir uygulama söz konusudur.

RFA'nın minimal invaziv ve perkütan uygulanabilir olması, özellikle cerrahi işlemin uygulanayamayacağı (inoperable) olgularda tümörün küçültülmesi ve yine özellikle bel ve boyun omurgası başta olmak üzere ağrılı eklem problemlerinde, ultrasonografi, bilgisayarlı tomografi ya da floroskopik kılavuzluk eşliğinde kullanılması büyük yararlar sağlamaktadır. Literatürde bu konuda oldukça fazla araştırma mevcut olup, bunların hemen tamamına yakını RFA'nın son derece başarılı sonuçlar verdiğini savunmaktadır. ${ }^{[2-4]}$

\section{RADYOFREKANS ABLASYON MEKANIZMASI}

Enerjinin belli bir miktarı aşan biçimde doku içerisine depolanması, canlı olan/olmayan bütün dokularda termal hasarlanmaya yol açar. RFA'da, bir jeneratör tarafindan oluşturulan mikrodalga radyasyonun bir elektrod (resiztör) ile dokuya iletilmesi ve yine bir 'elektrod ped' aracılığı ile de kapalı devre oluşturulması gerekir (Şekil 1).

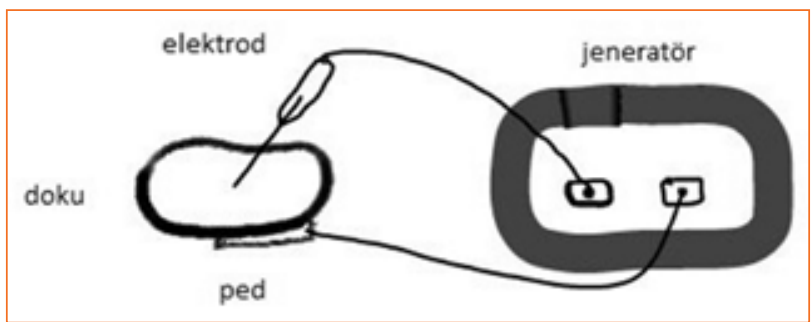

Şekil 1. RF ablasyon sistemi devresi.
RF dalgaları 900-2450 MHz frekans aralığındaki spektrum içerisinde yer almaktadır. Tıpta ise daha çok 450-500 kHz RF kullanılır. ${ }^{[5]}$ RFA kapalı devresinde yer alan jeneratör, bu dalga boyları içerisinde, dokuya göre seçim yapabilme olanağı da sunabilen elektromanyetik radyasyon üretmektedir. Üretilen bu enerji, özel kablolar aracılığı ile özel eletrodlara, ardından yukarıda da bahsedildiği üzere çeşitli yaklaşım yöntemleri ile dokuya iletilir. Seçilecek yaklaşım yöntemine göre özel elektrodlar mevcuttur. Açı cerrahi esnasında, büyük ya da aşırı kanama riski bulunan kitlelerin küçültülerek kolay kontrol edilebilir olmasını sağlamak amacı ile, direkt dokuya enerji ulaştıran ikili-üçlü elektrod kombinasyonları bulunduğu gibi, sakroiliak eklem ya da faset eklem denervasyonu amacı ile bir veya birden fazla iğne benzeri elektrod seçmek de mümkündür (Şekil 2). Enerjinin iletilmesini sağlamak için gereken kapalı devre, hastaya tespit edilen ped elektrodlar ve bu elektrodların jeneratöre bağlanması ile tamamlanmış olur.

Dokuya ulaşan RF dalgaları, doku içerisinde bulunan polar vaziyetteki molekül ve iyonlar üzerinde dönme, titreşim, yön değiştirme gibi etkilere neden olur. Molekül dışarıdan bir radyasyon enerjisi aldığında, ya bağlarını koparma ya da dönme ve titreşim gibi tepkiler verir. Burada oluşan atomik ya da moleküler etkileşim, yeni bir enerji salınımına yol açar. Ortamda biriken enerji, dokunun ısınmasına ve eğer bu ısı yüksek seviyelere çıkarsa hasar görmesine neden olur. RF dalgaları düşük enerjilidir. Dokuyu doğrudan yakmak

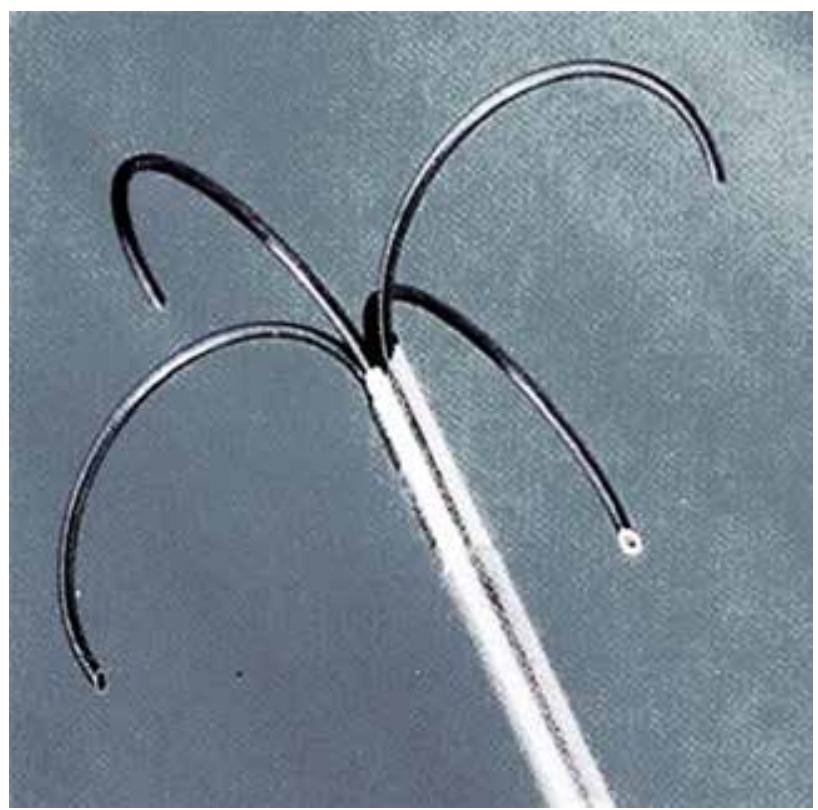

Şekil 2. Cluster ya da yumak şeklinde multi-tuned uygulanabilen elektrod. 
yerine, moleküler titreşim ile ortaya sekonder enerji çıkması sonucu, daha kontrollü bir tahribata yol açar. $\mathrm{Bu}$ ise, dokunun yanmasından çok 'erimesi ve büzüşmesi' (ablasyon and shrinkage) ile sonuçlanır. Burada, enerjinin büyüklüğü yanında enerjinin etki süresi de doğrudan etki eden başka bir parametredir. Dokunun maruz kalma süresi uzadıkça, daha fazla enerji depolanmasına bağlı olarak, ablasyon etkisi artar.

Isı depolanması radyofrekansın yoğunluğu ve süresi ile korelasyon gösterirken, soğuma bölgedeki kan dolaşımı yoğunluğu ile korelasyon göstermektedir. Komşu kan damarları, adeta bir ısı emici (heat sink effect) rolü üstlenir. Bu ise, daha fazla kanlanan dokularda seçilecek enerji yoğunluğu ve süreyi belirlemekte oldukça önemlidir. Hızlı soğuma ve elektrod-doku mesafesi, efektif ablasyon zonunu etkiler. Buradan kolaylıkla anlaşılacağı gibi, dokuya iletilecek enerji yoğunluğu ve süresi dokunun özellikleri ile belirlenmektedir.

Ayrıca, etkili bir ablasyon için, elektrodun mutlaka patolojik bölgenin mümkün olan en merkezi bölgesinde yer alması önemlidir. Aynı zamanda, ablasyon bölgesinin 'güvenli zon'da kalması da ayrıca dikkate alınması gereken bir konudur. Dolayısıyla, etkili bir ablasyon elde edebilmek için, ablasyon marjini, güvenli zon ve ablasyon zonunun en ideal bölgede olmasına gayret edilmelidir. Ablasyon zonunu ve etkinliğini, bir anlamda, yakından geçmekte olan kan damarları sınırlayıcı etkisi tayin eder. Güvenli ablasyon marjini yaklaşık 1 cm civarındadır. ${ }^{[5]}$

RFA'da, doku içerisinde depolanacak enerji ya da santigrat olarak ISı, genelde 100 derecenin altındadır. Ancak, $110^{\circ} \mathrm{C}$ 'lere kadar ısı depolanması mümkündür. Yapılan çalışmalarda, $80-100^{\circ} \mathrm{C}$ aralığında birçok dokuda etkili ablasyon için fark bulunmadığı bildirilmiştir. ${ }^{[1,2,5]}$

RFA sistemlerinde, kısaca bahsedecek olursak, ilk nesil cihazlara oranla günümüzde daha güçlü jeneratörler $(200 \mathrm{~W})$ kullanılmaktadır. Özellikle Cool tip sistem olarak isimlendirilmiş olan jeneratörler, empedansı ve ablasyon süresini otomatik olarak ayarlayabilmektedir. Bazı sistemler ablasyon ortamında ortaya çıkan gaz yoğunluğunu, bazıları ise birçok noktadan ıSı ölçümü sayesinde hem doğru hedefin seçilmesini hem de akım ve süre ayarlanmasını sağlamaktadır. Örneğin; dokuya doğru ısı ölçümü yapabilen sistemler, tümörün merkezinde daha yüksek ısı mevcudiyeti olacağından, daha etkili elektrod hedefi ve ablasyon alanı seçiminde yardımcı olabilmektedir. Cool tip sistemler, aynı zamanda çok iyi yalıtılmış ve soğutulmuş elektrodlar kullanmaktadır. Bu sayede, enerjinin istenen hedefe çevre dokular daha iyi korunarak ve kayıpsız bir şekilde ulaştırılması sağlanmaktadır. Özellikle geniş tümöral kitlelerin küçültülmesi amacı ile, tek bir elektrod yerine cluster ya da box sistem olarak nitelendirilen, birçok elektrodun organizasyonu ile elde edilen elekrod sistemlerinden yararlanılmaktadır (Şekil 2). Hatta, bu elektrod kümelerinin içerisinde multi-tuned yani aynı anda farklı voltaj ve sürelerde RF aktarımı sağlayan kombinasyonlar kullanılmaktadır. Yine bazı sistemlerde, elektrodlar ablasyon anında salin ile soğutularak, ablasyon zonunun daha fazla genişletilmesi sağlanmaktadır. Bütün bu gelişmelere ve RFA ağrı tedavisinde oldukça yeterli olmasına rağmen tümör tedavisinde ablasyon zonunun hala yetersiz kalması, çok kanlanan dokularda oluşan sink effect yani ısı emilmesi etkisi nedeni ile sınırı kullanıma sahiptir. Bu nedenle, özellikle tümör cerrahisinde kullanılmak üzere, mikrodalga teknolojisine yönelim söz konusudur. ${ }^{[1,3,5]}$ Bu sistemler Tablo 1'de karşılaştırılmıştır.

Ağrı tedavisinde, özellikle $80-60^{\circ} \mathrm{C}$ 'de uygulanan RF ablasyon sonrası bazen bölgesel ağrı kalması, maalesef en önemli dezavantaj gibi görülmektedir. Bu nedenle, son yıllarda devamlı akım veren konvansiyonel RFA sistemlerinin bir alternatifi olarak 'pulse RFA' sistemleri geliştirilmiştir. Bu sistemin en önemli üstünlüğü, akımı sürekli vermek yerine daha küçük alana ısı diffüzyonunu azaltma imkanı sunması, daha güvenli ablasyon alanı oluşmasını sağlaması ve daha az dokuda nekroza neden olması, böylece de işlem sonrası hasta şikayetlerinin azaltılmasını mümkün kılmasıdır. Pulse RFA'da elektrod ucunda yaklaşık $42^{\circ} \mathrm{C}$ 'lere çıkan ısı depolanması gösterilmiş olmakla beraber, ağrıyı azaltıcı etkisi ve nöral dokuyu Vallerian dejenerasyonuna uğratmadan kesme mekanizması tam olarak açık değildir. ${ }^{[6-8]}$ $\mathrm{Biz}$ de, özellikle faset eklem blokajı işlemlerinde, servikal bölge için pulse RFA uygulamaktayız.

Tablo 1. RF sistemlerinin kısaca karşılaştırılması

\begin{tabular}{llll}
\hline RF & Enerji & Etki & Kullanım alanı ve ablasyon zonu \\
\hline Continued RF & $100-500 \mathrm{~Hz}, 60-90 \mathrm{~s}$ & $65-75^{\circ} \mathrm{C}$ & Tüm dokularda ablasyon (2-12 mm) \\
Pulsed RF & $2 \mathrm{~Hz}-50 \mathrm{kHz}, 20 \mathrm{~ms}-320 \mathrm{~s}$ & $\leq 42^{\circ} \mathrm{C}$ & Ablasyon, sinir dokusu hasarı oldukça sınırı. Koagülasyon (2-20 mm) \\
Cooled RF & $100-1000 \mathrm{kHz}, 50-450 \mathrm{~s}$ & $50-90^{\circ} \mathrm{C}$ & Tüm dokuarda ablasyon, koagülasyon (2-30 mm)
\end{tabular}




\section{RFA'NIN KLINIK UYGULAMALARI}

Son on yılda RF uygulamaları, perkütan cerrahi girişimlerin artmasına paralel olarak geniş bir kullanım alanı bulmuştur. Bunda, RFA'nın göreceli olarak ucuz olması yanında, uyum ve güvenilirliğinin yüksek olması rol oynamıştır. Solid tümörlerin ve metastatik iskelet sistemi tümörlerinin ablasyonundan, faset eklem ya da diz eklemlerinin denerve edilmesine kadar birçok amaçla kullanılmaktadır (Tablo 2).

Özellikle solid tümörlerin tedavi ya da kontrolünde, tek başına küçültücü ya da sağaltıcı tedavi olarak, açık cerrahinin yardımcı bir komponenti olarak ya da kemoterapi ile birlikte uygulanabilmesi, çok büyük bir avantajıdır. ${ }^{[4,5,7]}$

Tablo 2. RF endikasyonları

\begin{tabular}{|c|c|}
\hline Kas iskelet sis & eminde radyofrekans kullanımı \\
\hline Ağrı tedavisi & \\
\hline Omur & kaynaklı ağrılar \\
\hline & Faset eklem kaynaklı ağrılar \\
\hline & Disk patolojilerinde ablasyon \\
\hline & Nörotomi \\
\hline Eklem & ğrıları \\
\hline & Diz ve diğer eklemlerde sinir blokajı \\
\hline & Sakroiliak eklem blokajı \\
\hline Kas ve & asya \\
\hline & Fibromiyalji benzeri durumlar \\
\hline & Nedeni bilinmeyen ağrılı noktalarda \\
\hline Tümörler & \\
\hline Primer & \\
\hline & Osteoid osteoma \\
\hline & Tümör küçültme \\
\hline & Rezeksiyon \\
\hline Metas & atik \\
\hline & Omurga metastazlarında tümör ablasyonu \\
\hline Cerrahi amaçlı & \\
\hline Artros & opik \\
\hline & Debridman \\
\hline & Eritme (shrinkage) \\
\hline & Kapsül germe \\
\hline & Denervasyon \\
\hline & Eksizyon \\
\hline Açık ce & rahide \\
\hline & Kesici olarak kullanım \\
\hline & Koagülasyon \\
\hline & Tümör eksizyonunda yardımcı işlem olarak \\
\hline
\end{tabular}

Renal, karaciğer, akciğer tümörleri gibi birçok iç organ (visseral) tümörlerinde, genel durum bozukluğu olan hastalarda ağrı ve bazı semptomların geriletilmesinde ve ameliyat edilemeyen durumlarda dahi uygulama yeri mevcuttur. Bu açıdan değerlendirildiğinde, genel durum bozukluğu bulunan bu tür hastaların ağıı kontrolü için değerli bir seçenek olarak değerlendirilmektedir.

Diğer taraftan, özellikle bazı konjenital ileti bozukluğuna bağlı kardiyak aritmilerin tedavisinde, intrakardiyak aberran yolların ablasyonu bu alanda oldukça yaygın kullanıma sahiptir. ${ }^{[8,9]}$

Bütün bu uygulamaların yanında, RFA kas iskelet sistemi hastalıklarında ve ağrılı durumlarda oldukça yaygın kullanım alanına sahiptir.

Kas iskelet sistemi patolojilerine bağlı ağrılı durumlarda, uygulama daha kontrol edilebilir ve ulaşım vasıtaları da daha fazladır. Kemik metastazları dışında, RFA büyük oranda ağrı kontrolü amacıyla uygulanmaktadır. Aşağıda, kas iskelet sistemi uygulamalarına kısa metinler içerisinde değinilecektir.

\section{KAS ISKELET SISTEMI TÜMÖRLERINDE RFA}

Osteoid osteoma gibi bazı primer tümörlerde, RFA doğru biçimde uygulandığı takdirde tam bir kür sağlayabilmektedir. Elektrodun tümörün merkezine yerleştirilmesi ve etkili ablasyon sahası içerisinde kalmasının sağlanması, eğer yeterli süre ve miktar enerjinin transferi ile birleştirilirse, kısa sürede ve tamamen perkütan bir yaklaşımla sonuç alınması mümkündür. Elektrodun kemik içerisinde uygun bölgeye yerleştirilmesinde kemik biyopsi enstrümanlarından yararlanılması, oldukça yaygın bir uygulamadır. Bilgisayarlı tomografi (BT) görüntüleri kılavuzluğunda $14 \mathrm{G}$ penetrasyon seti kemik patolojisinin merkezine yerleştirildikten sonra, RF elektrod bu set içerisinden tümörün merkezine ilerletilir. Eğer biyopsi gereksinimi varsa, penetrasyon kanülünden önce biyopsi iğnesi ile girilerek patolojik kemik örneği de elde edilebilir. RFA'nın biyopsi işleminden sonra uygulanmasına dikkat edilmelidir.

\section{Metastatik Kemik Tümörlerinin Cerrahisinde RFA Kullanımı}

İyi bilindiği üzere, metastatik kemik tümörleri oldukça ağrılı durumlardır. Bu tür hastalarda, ağrının kontrolü ve azaltılması çoğu zaman neredeyse imkansızdır. Aşııı ağrılı hastalarda, opioid kullanımı ile dahi çoğu zaman istenen sonuç elde edilemeyebilir. Burada, hem birden fazla tutulum ve ağrının çok bölgeden kaynaklanmasına bağlı agrevasyon, hem 
de hastalığın doğası gereği, ortama salınan kimyasallar ve mekanik etkinin sürekliliği önemli oranda rol oynamaktadır. ${ }^{[10]}$ Dolayısıyla, metastaz kaynaklı kemik ağrılarında, hem mekanik sinir iritasyonunun azaltılması hem de ortamda üretilen ağrılı kimyasalların azaltılması hedeflenmelidir.

Ancak yine bilindiği üzere, metastatik kemik tutulumları kanser hastaları için en genel morbidite nedenidir. Bu tür hastalarda, genellikle yaşam süreleri ve beklentileri sınırlanmıştır. Hem hastalığın doğası hem de radyoterapi, kemoterapi gibi hastayı dirençsiz kılan tedavilere bağlı olarak, bu tür hastalarda girişimsel işlemler tek başına hastayı daha da riske atma tehlikesi taşımaktadır.

Günümüzde, metastatik kemik tümörlerinin ağrı kontrolünde radyasyon terapisi, sistemik kemoterapi, hormonal terapi, cerrahi eksizyon ya da stabilizasyon ve ağrı kesici ajanlar yaygın olarak uygulanmaktadır. Fakat bütün bu yöntemler bazen tek bazen de kombine uygulansa da, istenen sonuç ne yazık ki elde edilemeyebilir. ${ }^{[10,11]}$ RFA ise, bütün bu ağrı kontrolü yöntemlerine birçok yönden oldukça avantajlı bir seçenek olabilmektedir. ${ }^{[3,4,10,11]}$ Termonörotomi etkisi ile, direkt olarak sinir iletimini engelleme ve ağrıyı azaltma potansiyeli vardır. Ayrıca ablasyon etkisi ile, hem tümörün küçülmesini sağlayarak bir miktar basıyı azaltır hem de tümörün rijiditesi üzerine etki ederek rahatsız edici (irritating) etkisini azaltabilir. Bütün bu etkiler elde edilirken perkütan yolla uygulanabilir olması ve zaten direnci azalmış hastalar için ek yara problemi yaratmaması, tercih nedeni olmaktadır. Aynı zamanda, metastatik kemik tümörlerinde RFA sonrası sementasyon yapıldığında, daha etkili sonuç alındığını ileri süren çalışmalar da mevcuttur. ${ }^{[12]}$

\section{RFA'nın Kemik Eklem Patolojilerinde Yeri}

RF enerjisi, eklem cerrahisinde daha çok artroskopinin bir komponenti olarak kullanılmaktadır. Özellikle omuz kalça ve diz artroskopik girişimlerinde, son derece gelişmiş RF elektrodları mevcuttur. Cerrahi süreyi kısaltması ve güvenli, kontrol edilebilir bir ablasyon marjini tayin edilebilir olması bunda etkili olmuştur. Bu amaçla, eklemde termal kapsülorafi, bazı kemik kanamalarının durdurulmasında ve kapsüler gevşetme amacı ile kesi yapmak için kullanılmaktadır. ${ }^{[13-15]}$

Özellikle kronik ağrılı dizde geniküler sinir ablasyonu yolu ile, artritik diz ağrılarının kontrolü üzerine literatür çalışmaları mevcuttur. ${ }^{[16,17]}$ Bunun gibi, yine omuz ve dirsekte de, çok yaygın olmamakla birlikte gerek sinir ablasyonu gerekse patolojik doku ablasyonu amacı ile uygulama mümkündür.

\section{Kronik Omurga Hastalıklarında RFA Uygulamaları}

Omurga kaynaklı kas iskelet sistemi ağrılı durumları oldukça yaygın olup, bazen tedavide ciddi başarısızlıklar söz konusu olabilmektedir. ${ }^{[18-20]}$ Omurga kökenli ağrılar, bütün ağrı formlarında karşımıza çıkabilmektedir. Bu ağrılara nörodefisit ya da somatik bulgular eşlik edebilir. En önemli problem ise, özellikle yaşlı hasta gruplarında, yaygın eklem ve iskelet sistemi problemleri bulunan hastalarda süperpoze ağrıların olması durumunda, bunların ayrımının yapılma zorluğudur. Bacak ağrısı bulunan bir hastada, kalça, diz, ayak bileği ve omurga kaynaklı ağrılar birlikte görülebilir. Ağrıların kökenini tespit edilmesi, tedavinin sonuç alıcı olmasının en önemli belirleyicisidir.

Omurga kaynaklı ağrılar, omurga kompleksinin nöral ya da iskelet yapısından kaynaklanıyor olabilir. Elbette bu ağrıların karakter farklılığı vardır. Ancak, biz burada daha çok RFA uygulanan omurganın iskelet sistemi yapısı kaynaklı ağrılarından bahsedeceğiz.

Omurga iskeleti, ya doğrudan ya da dolaylı olarak ağrıya neden olabilir. Doğrudan ağrıları, elbette öncelikle patolojinin oluştuğu anatomik bölgede görürüz. Bunların başında, omurga yapısal kompleksi içerisinde yer alan disk, bağ ya da faset eklem kaynaklı ağrılar gelmektedir. Disk ve foraminal boşluk anatomik parçalarından kaynaklanan ağrılar, oldukça karışık karakterde, hem anatomik bölge hem de ilgili sinir çıkışının beslediği uzak alanlarda karşımıza çıkma eğilimindedir. Kronikleşmiş bu tür ağrılarda RFA çok sınırlı olmakla beraber, özellikle son yıllarda popülarize olan endoskopik omurga cerrahisinin tamamlayıcı bir enstrümanı olarak uygulanabilmektedir. ${ }^{[19,21,22]}$ Ancak, sinir basıları nedeni ile ekstremite ağrılarında doğrudan RFA uygulaması, sadece disk kaynaklı patolojilerde yaygındır. Disk kaynaklı patolojilerde, perkütan nükleoplasti gibi direkt olarak disk içerisine RFA uygulanması yanın$\mathrm{da}$, minimal invaziv girişimlerin bir bileşeni olarak da uygulanabilmektedir.

Disk dışında, omurga kaynaklı ağrılı patolojilerde ise RFA doğrudan uygulanabilir. Bunlar daha çok, faset eklemi ilgilendiren aksiyel bel, sırt ve bazen de boyun ağrıları olabilir. Literatürde, altı aylık süreler için ağrısız interval elde edilmesi konusunda fikir birliği oluştuğu söylenebilir. Ancak, altı aylık süreden sonra yeniden ağrı oluşma ihtimali göz önünde bulundurulmalıdır. $[19,20]$

\section{Faset Eklem Blokajı}

Faset eklem blokajı, ilgili seviyede çıkan sinir kökünden ayrilarak faset eklem ve çevresini innerve eden mediyal dalın nörotomisi işlemidir. 
Kronik bel sırt ve boyun ağrılarının büyük çoğunluğu faset eklem kaynaklıdır. Servikal faset eklem patolojilerinde ağrı, baş, boyun ve omuzlara yayılabilirken; dorsal faset eklem patolojilerinde ağrı, nöraljik karakterde paraspinöz bölgede ve üst lumbar bölgede görülebilir. Lomber faset eklem patolojilerinde ise, ağrı aksiyel olarak bel bölgesinde her iki gluteal bölgeye ve uyluk üst bölgelerine yayılabilir. Psödoradiküler yayılım gösterebildiğinden, özellikle bel bölgesinde faset eklem patolojisine bağlı ağrıları ayırt etmek kolay değildir. Bazen, RFA öncesi test amacı ile ilgili bölgelere lokal analjezik enjeksiyonu yardımcı olabilir. ${ }^{[23,24]}$

Burada, skopi ya da BT altında, elektrodun faset eklem lateraline yakın yerleştirilmesiyle ve $80^{\circ} \mathrm{C}$ civarında ya ısıtarak ya da pulse RF uygulayarak median dal blokajı yapılmaktadır (Şekil 3-5). Hastaların çoğu, günü birlik işlem olarak, hastanede yatış gerektirmeden aynı gün taburcu edilebilmektedir. İşlem sonrası bazı hastalarda, uygulamanın yapıldığı bölgelerde ağrı ve rahatsızık hissi olabilir bu genellikle ağrı kesici ilaçlarla kontrol edilebilir.

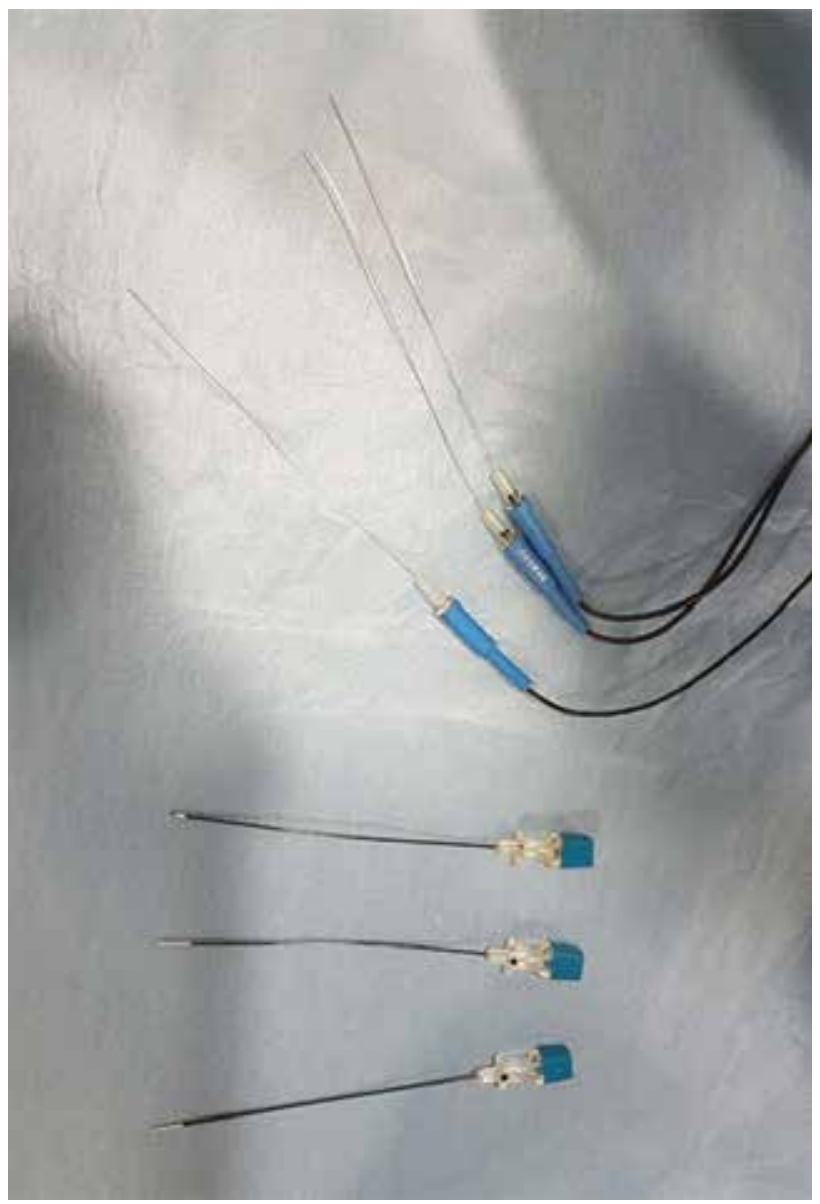

Şekil 3. 24 gauge iğne ve elektrodlar.

\section{Sakroiliak Eklem RFA Uygulaması}

Yukarıda da kısaca değinildiği üzere, bel ağrısı oldukça yaygın bir toplum sağ|ı̆ı problemidir ve ağrının kaynağına ulaşılması, günümüzde gelişmiş teknolojinin kullanılmasına rağmen hala zordur. Çünkü, bu bölgede ağrı kaslardan, bağlardan, sinir köklerinden,

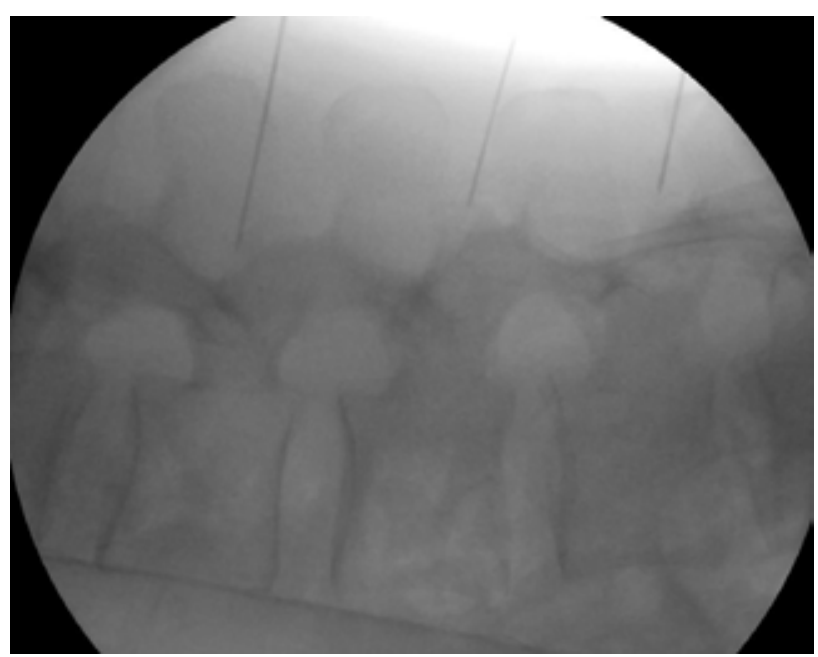

Şekil 4. Skopi altında elektrodların faset eklem çevresine yerleştirilmesi.

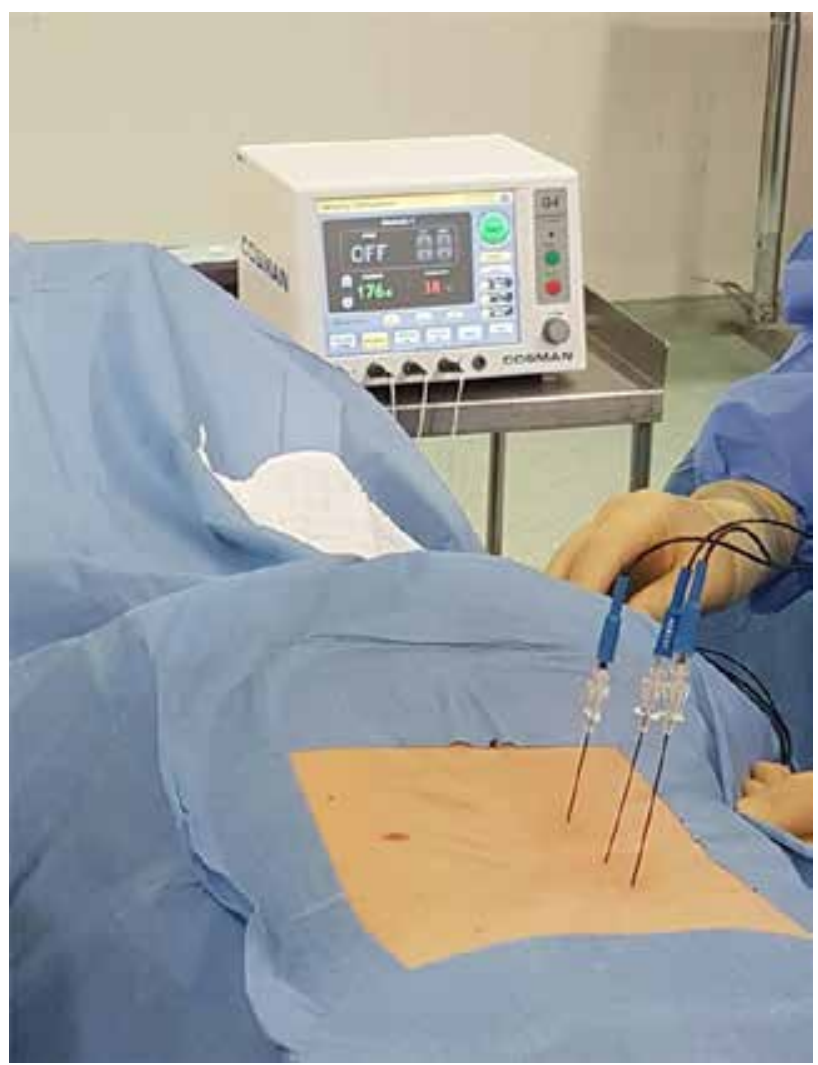

Şekil 5. RF ablasyonun faset eklem denervasyonu için uygulanması. 
intervertebral disklerden, faset ve sakroiliak eklemlerden kaynaklanabilmektedir. Bütün bu anatomik yapıların her biri, tek başlarına ya da çoğu zaman birlikte potansiyel ağrı nedenidir. Sistematik literatür çalışmaları, sakroiliak eklem kaynaklı ağrıların \%10-25 oranında görüldüğünü bildirmektedir. ${ }^{[25]}$

Sakroilaik RFA'da, elektrodlar eklemi innerve eden sensoriyel sinir uçlarının çıktığı foramenlerin hemen lateraline ya da eklemin hemen mediyaline yerleştirilerek, yine devamlı ya da pulse RFA uygulanması şeklindedir. Sedasyon altında günübirlik işlem olarak uygulanabilir.

Hem faset eklem hem de sakroiliak eklemde, RFA altı aylık periyodlar ile tekrarlanabilir. Çünkü, bazı hastalarda reinnervasyon sonucu ağrının tekrar nüksetmesi mümkündür. ${ }^{[20,21,23,25]}$

\section{RFA KONTRENDIKASYONLARI}

RF kullanımının uygulanmasında sakınca bulunan durumlar mevcuttur (Tablo 3). Bunlara aşağıda kısaca değinilecektir.

Enfeksiyon RFA için en temel kontrendikasyonlardan birisidir.

RFA'nın kontrendikasyonları, uygulandığı doku ve organlara göre farklılık gösterir.

Visseral doku tümörlerinde ya da bazı kemik tümörlerinde duktus ve damarsal yapıların patolojik bölgeye çok yakın olması, olası yaralanma halinde fistül ya da akut kanama riskinin arttığı bütün durumlar, kontrendikasyon kapsamındadır. Dolayısıyla RFA, mide, kolon ve ince barsak komşuluğundaki doku ve tümörlerde uygulanması kontrendikedir. ${ }^{[26]}$

Kanama eğiliminin arttığı (Prothrombin activity $<\% 50$, Prothrombin time ratio $>\% 50$, Platelet count $<50 \times 109 / \mathrm{L}$, INR $>1,4$ ) ve yakın zamanda antikoagülan kullanmış hastalarda uygulanması önerilmemektedir. ${ }^{[26,27]}$

Tablo 3. Kontrendikasyonlar

İçi boş organlara komşu patolojilerde uygulama

Kardiyak aritmi riski olan hastalarda kalbe yakın uygulama

Enfeksiyon

Diyabet (kan şekeri kontrol altında olmayan)

Kanama riski yükşelmiş kitle ve tümörlere karşı

Büyük damarlara yakın yerleşimler

Kanama-pıhtılaşma bozuklukları
Yine, kan şekeri kontrol altında olmayan diyabetik hastalarda, kan şekeri regülasyonu sağlanıncaya kadar uygulanması kontrendikedir.

Kardiyak bölgede kalbe çok yakın dokular için uygulanması, disaritmi, vazovagal reaksiyonlar ve kardiyak enfarktüs riskini arttırdığından, RF uygulanması önerilmemektedir. ${ }^{[26]}$

Titanyum olduğundan emin olunan implantların bulunması kesin kontrendikasyon oluşturmamakla beraber, destrüksiyon ve yanık riski bulunduğu konusunun hasta ile paylaşılmasında yarar vardır. ${ }^{[26]}$

\section{RFAT KOMPLIKASYONLARI}

RFAT komplikasyonları, uygulandığı dokuya göre değişir. Ancak, RFA uygulamalarının en ürkütücü komplikasyonları, şüphesiz ki visseral doku uygulamalarında intestinal doku yaralanmaları ve sinir hasarlarıdır. ${ }^{[28,29]}$

Değişen oranlarda, RFAT'a bağı komplikasyonlar bildirilmiştir. İç organ yaralanmaları \%1,5 ile \%0,07 arasında bir oranda değişiklikler göstermektedir.

Kas iskelet sistemi uygulamalarında da başlıca komplikasyonlar; geçici ağrı, rahatsızlık hissi, anestezik maddelere karşı alerjik reaksiyonlar, ağrının kötüleşmesi, uygulama yerinde lokal yanık ya da fistülize yara oluşması, enfeksiyon ve kalıcı ya da geçici sinir hasarı olarak sıralanabilir. Literatürde çok farklı oranlar bildirilmektedir; ancak yine $\% 1$ oranda rahatsızık hissi, geçici ağrı oluşması ve enfeksiyon bildirilmiştir. Kalıcı sinir yaralanması ise \%0,01 oranında bildirilmiştir. ${ }^{[28,29,30]}$

Diğer önemli komplikasyonlardan birisi ise, elektrod pedlerin uygun olmayan yerleşimi nedeni ile, hastada yanıkların ve buna bağlı ülserlerin oluşmasıdır. Literatürde bu tür komplikasyonlar $\% 0,06-0,3$ oranlarında bildirilmiştir. ${ }^{[30]}$

\section{SONUÇ}

RF ile tedavi girişimleri, dokuya kolay ve kontrol edilebilir enerji transferine imkan tanıması ve bu sayede, kesme, eritme ya da küçültme, bazen de ısıtma etkisi nedeni ile yaygın olarak kullanılmaya başlanmıştır. Ortopedik cerrahide de, başta artroskopik girişimlerde yardımcı bir araç olarak olmak üzere, girişimsel ağrı tedavisinde giderek yaygınlaşmaktadır. Özellikle elektrod teknolojisinin giderek gelişmesi yanında, üretilen RF enerjisinin iletimi ve hedef seçiminde geliştirilen senkronize elektromiyogram (EMG) ölçümü, patolojik bölgelerin ısı farkı tespiti yöntemi ile tespiti gibi yeniliklerin eklenmesi, tekniğin etkinlik ve güvenilirliğini günden güne arttırmaktadır. 


\section{KAYNAKLAR}

1. Blouin LT, Marcus FI, Lampe L. Assessment of effects of a radiofrequency energy field and thermistor location in an electrode catheter on the accuracy of temperature measurement. Pacing Clin Electrophysiol 1991;14(5 Pt 1):807-13.

2. Haines DE, Watson DD, Verow AF. Electrode radius predicts lesion radius during radiofrequency energy heating. Validation of a proposed thermodynamic model. Circ Res 1990;67(1):124-9.

3. Rozen G, Ptaszek L, Zilberman I, Cordaro K, Heist EK, Beeckler C, Altmann A, Ying Z, Liu Z, Ruskin JN, Govari A, Mansour M. Prediction of radiofrequency ablation lesion formation using a novel temperature sensing technology incorporated in a force sensing catheter. Heart Rhythm 2017;14(2):248-54. Crossref

4. Enomoto $\mathrm{M}$, Tago $\mathrm{T}$, Kasahara $\mathrm{K}$, Wada $\mathrm{T}$, Matsudo $\mathrm{T}$, Murakoshi Y, Ishizaki T, Kasuya K, Katsumata K, Tsuchida A. Radiofrequency Ablation Combined with Hepatectomy for the Treatment of Liver Metastases from Colorectal Cancer. Gan To Kagaku Ryoho 2016;43(12):1449-51.

5. Queiroz M, Duarte R, Chan C, Saldanha L, Mitre A, Srougi $M$. Determination of the most efficient temperature for radiofrequency ablation of renal cells: a prospective study in dogs. J Endourol 2009;23(2):313-6. Crossref

6. Kutlu OC, Chan JA, Aloia TA, Chun YS, Kaseb AO, Passot G, Yamashita S, Vauthey JN, Conrad C. Comparative effectiveness of first-line radiofrequency ablation versus surgical resection and transplantation for patients with early hepatocellular carcinoma. J Cancer 2017. [Epub ahead of print] Crossref

7. Xu Y, Shen Q, Wang N, Wu PP, Huang B, Kuang M, Qian GJ. Microwave ablation is as effective as radiofrequency ablation for very-early-stage hepatocellular carcinoma. Chin J Cancer 2017;36(1):14. Crossref

8. Wei $W$, Liao $H$, Xue $Y$, Fang $X$, Huang J, Liu $Y$, Deng $H$, Liang $Y$, Liao Z, Liu F, Lin W, Zhan X, Wu S. Long-Term Outcomes of Radio-Frequency Catheter Ablation on Ventricular Tachycardias Due to Arrhythmogenic Right Ventricular Cardiomyopathy: A Single Center Experience. PLoS One 2017;12(1):e0169863. Crossref

9. Arıkan $Y$, Yavuz U, Lapcin O, Sökücü S, Özkan B, Kabukçuoğlu $Y$. Percutaneous radiofrequency ablation for osteoid osteoma under guidance of threedimensional fluoroscopy. J Orthop Surg (Hong Kong) 2016;24(3):398-402. Crossref

10. Nakatsuka A, Yamakado K, Uraki J, Takaki H, Yamanaka T, Fujimori M, Hasegawa T, Sakuma H. Safety and Clinical Outcomes of Percutaneous Radiofrequency Ablation for Intermediate and Large Bone Tumors Using a MultipleElectrode Switching System: A Phase II Clinical Study. J Vasc Interv Radiol 2016;27(3):388-94. Crossref

11. Bornemann R, Jansen TR, Wollny M, Wirtz DC, Pflugmacher $R$. Clinical aspects of the problem of vertebral metastases, possibilities of modern treatment methods, considering especially radiofrequency ablation. Z Orthop Unfall 2014;152(4):351-7. Crossref

12. Maugeri R, Graziano F, Basile L, Gulì C, Giugno A, Giammalva GR, Visocchi M, lacopino DG. Reconstruction of Vertebral Body After Radiofrequency Ablation and Augmentation in Dorsolumbar Metastatic Vertebral Fracture: Analysis of Clinical and Radiological Outcome in a Clinical Series of 18 Patients. Acta Neurochir Suppl 2017;124:81-6. Crossref

13. Huber M, Loibl M, Eder C, Kujat R, Nerlich M, Gehmert S. Effects on the Distal Radioulnar Joint of Ablation of Triangular Fibrocartilage Complex Tears With Radiofrequency Energy. J Hand Surg Am 2016;41(11):1080-6. Crossref
14. Rocco P, Lorenzo DB, Guglielmo T, Michele P, Nicola M, Vincenzo D. Radiofrequency energy in the arthroscopic treatment of knee chondral lesions: a systematic review. $\mathrm{Br}$ Med Bull 2016;117(1):149-56. Crossref

15. Lalam RK, Cribb GL, Cassar-Pullicino VN, Cool WP, Singh J, Tyrrell PN, Tins BJ, Winn N. Radiofrequency thermoablation of PVNS in the knee: initial results. Skeletal Radiol 2015;44(12):1777-84. Crossref

16. Santana Pineda MM, Vanlinthout LE, Moreno Martín A, van Zundert J, Rodriguez Huertas F, Novalbos Ruiz JP. Analgesic Effect and Functional Improvement Caused by Radiofrequency Treatment of Genicular Nerves in Patients With Advanced Osteoarthritis of the Knee Until 1 Year Following Treatment. Reg Anesth Pain Med 2017;42(1):62-8. Crossref

17. Wong J, Bremer N, Weyker PD, Webb CA. Ultrasound-Guided Genicular Nerve Thermal Radiofrequency Ablation for Chronic Knee Pain. Case Rep Anesthesiol 2016;2016:8292450. Crossref

18. Becker $\mathrm{S}$, Hadjipavlou $\mathrm{A}$, Heggeness $\mathrm{MH}$. Ablation of the basivertebral nerve for treatment of back pain: a clinical study. Spine J 2017;17(2):218-23. Crossref

19. Manchikanti L, Hirsch JA, Falco FJ, Boswell MV. Management of lumbar zygapophysial (facet) joint pain. World J Orthop 2016;7(5):315-37. Crossref

20. Shanthanna $H$. Investigating the Effects of Pulsed Radiofrequency on Dorsal Root Ganglion in Chronic Lumbar Radicular Pain Patients: Is It Not Important that We Ask the Right Question, the Right Way, on an Appropriate Sample of Patients? Pain Med 2016;17(2):374-5. Crossref

21. Maas ET, Ostelo RW, Niemisto L, Jousimaa J, Hurri $H$, Malmivaara A, van Tulder MW. Radiofrequency denervation for chronic low back pain. Cochrane Database Syst Rev 2015;(10):CD008572. Crossref

22. Jeong SY, Kim JS, Choi WS, Hur JW, Ryu KS. The effectiveness of endoscopic radiofrequency denervation of medial branch for treatment of chronic low back pain. J Korean Neurosurg Soc 2014;56(4):338-43. Crossref

23. Leggett LE, Soril LJ, Lorenzetti DL, Noseworthy T, Steadman $R$, Tiwana S, Clement F. Radiofrequency ablation for chronic low back pain: a systematic review of randomized controlled trials. Pain Res Manag 2014;19(5):e146-53.

24. Poetscher AW, Gentil AF, Lenza M, Ferretti M. Radiofrequency denervation for facet joint low back pain: a systematic review. Spine (Phila Pa 1976) 2014;39(14):E842-9. Spine (Phila Pa 1976) 2014;39(14):E842-9. Crossref

25. Choi W-S, Kim J-S, Ryu K-S, Hur J-W, Seong J-H, Cho H-J. Endoscopic Radiofrequency Ablation of the Sacroiliac Joint Complex in the Treatment of Chronic Low Back Pain: A Preliminary Study of Feasibility and Efficacy of a Novel Technique. Biomed Res Int 2016;2016:2834259. Crossref

26. Kohlschein $P$, Bänsch D, Dreißiger K, Schuff-Werner $P$. Exclusion of thrombocytopenia as a contraindication for invasive radiofrequency ablation in a patient with paroxysmal atrial fibrillation by using magnesium anticoagulation instead of EDTA. another case of anticoagulant-induced pseudothrombocytopenia. Heart Surg Forum 2015;18(3):E090-2. Crossref

27. Tatli S, Tapan U, Morrison PR, Silverman SG. Radiofrequency ablation: technique and clinical applications. Diagn Interv Radiol 2012;18(5):508-16. Crossref

28. Tian QH, Wu CG, Gu YF, He CJ, Li MH, Cheng YD. Combination radiofrequency ablation and percutaneous osteoplasty for palliative treatment of painful extraspinal bone metastasis: a single-center experience. J Vasc Interv Radiol 2014;25(7):1094-100. Crossref

29. Dierselhuis EF, Jutte PC, van der Eerden PJ, Suurmeijer AJ, Bulstra SK. Hip fracture after radiofrequency ablation therapy for bone tumors: two case reports. Skeletal Radiol 2010;39(11):1139-43. Crossref 